\title{
Conspiracy can't be proved
}

\section{Washington}

ANIMAL-WELFARE activists say that they have found no evidence to support their claim that the US government funded a University of Pennsylvania scientist to attack animal-rights efforts.

The researcher, veterinarian Adrian Morrison, was the target of an attack on 13 January 1990 by the Animal Liberation Front (ALF), an underground animalrights group. Activists broke into his office and stole several drawers of his files, including his research grant applications and hundreds of personal letters, in search of evidence that he received federal funding for his animal-research advocacy efforts.

Morrison was targeted by the ALF "because he staunchly defends beleaguered researchers, wherever they may be", said a press release issued by People

\section{GLOBAL CHANGE}

\section{No surprises in leaked report}

\section{London}

A PRELIMINARY version of the report from the science working group of the Intergovernmental Panel on Climate Change (IPCC), which is due to be made public in late May, has been leaked to Independent Television News in the United Kingdom. The IPCC scientists predict that by the middle of the next century, global temperatures will be an average $3^{\circ} \mathrm{C}$ higher than today, with average rainfall some 7 per cent higher. Sea level may rise by about $45 \mathrm{~cm}$. But there will be local variations, the IPCC predicts, with greater warming in the northern hemisphere, and regional droughts and flooding.

A similar view has been reached elsewhere but the report is important in the influence it is expected to have on official policy throughout the world. The report comes from one of three working groups within IPCC (the others are examining the impacts of climate change and policy to combat the problem).

About 200 scientists, under the chairmanship of John Houghton of the UK Meteorological Office, were involved in the working group, and met at a series of workshops over the past year.

Geoff Jenkins, a member of the working group, also at the Meteorological Office, says that the report has been sent out to more than 100 scientists for peer review. Given the large number of people involved in compiling and reviewing the report, he thinks it was almost inevitable that the report's findings would be leaked in advance of the publication date.

Peter Aldhous for the Ethical Treatment of Animals (PETA), an animal-rights group that frequently releases information obtained by the ALF. Although the activists also criticized Morrison's use of cats in his own work on sleep disorders, the break-in was the first time a scientist had been targeted primarily for his support of animal research.

"ALF removed documents that will help establish the deep-seated corruption of the anti-animal Nazis", PETA cofounder Alex Pacheco promised last month in PETA News, the organization's magazine. But in the months since the break-in, no evidence has surfaced to support the claim that Morrison was being surreptitiously supported by the US Public Health Service.

Animal-rights activists have pointed out that a memorandum written in 1987 by Frederick Goodwin, then director of intramural research at the National Institute of Mental Health, called for a more "pro-active" opposition to the animalrights movement. One of Goodwin's suggestions was "to fund special fellowships in research advocacy for investigators who may wish to include a year or two of such activity in their career". Morrison was seen by animal-rights activists as the first of such federally funded animalresearch advocates.

Mary Beth Sweetland, a PETA investigator who has been analysing the stolen files, said last week that "I don't think that anything in the files will provide absolute proof of what we believe to be a binding link between NIH [National Institutes of Health] and Morrison".

Goodwin, who is now the director of the Alcohol, Drug and Mental Health Administration, the sister agency to the $\mathrm{NIH}$, says Morrison was funded for research alone. "Everything he's done and I think he's done a lot of courageous things - he's done on his own", says Goodwin.

Morrison has been on sabbatical leave since the attack. He says his advocacy efforts were motivated by his concern about the tactics of animal-rights groups. "The claims of the animal-rights extremists against biomedical research and individual researchers [have] been so distorted and vicious, and the threat to the public's health so great, that I could not stand by quietly", he says.

His stolen files do show that Morrison, who is chairman of the Society of Neuroscience's Committee on Animals in Research, wrote hundreds of letters (319 in 1989 alone) in support of animal research, testified in court and gave dozens of lectures in defence of animal research and animal researchers.

G. Christopher Anderson

\section{Ministerial time up for Mr Jones \\ Sydney}

BARRY Jones, the colourful and controversial science minister who believes he raised Australia from being 'the lucky country' to being 'the clever country', has lost the post he has held for seven years as Minister of Science and Technology following the recent federal election.

Jones has been replaced by Simon Crean, an avowed 'economic rationalist', whose additional role as Minister Assisting the Treasurer may deflect his attention away from science and technology. Crean has been brought into the cabinet as new blood and is a strong candidate to take over from the present Treasurer, Paul Keating, who seems certain to be elected leader of the Australian Labor Party.

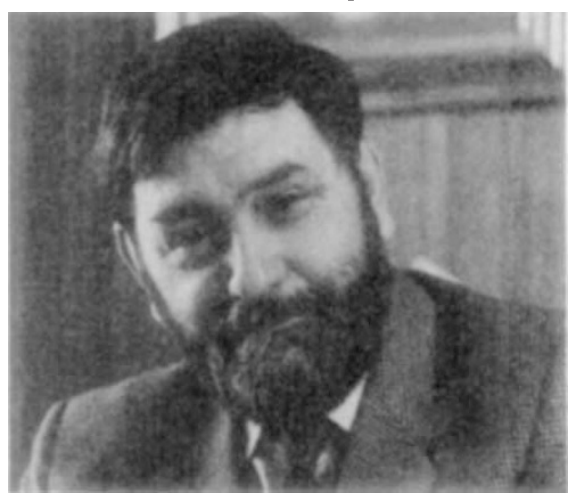

Barry Jones - replaced by 'new blood'.

In a protest over his dismissal, Jones has threatened to resign from Parliament and force a risky by-election. The Labor government won the 24 March election by the small margin of 78 seats to 69 for the opposition. The government is thought to be trying to persuade Jones to remain in Parliament by offering him a position such as ambassador to UNESCO. Sources within Parliament say he has refused.

Jones was elected in 1972 and appointed Opposition spokesperson on science and technology in 1980, becoming minister following the election of the Hawke government in 1983

Jones told the Sydney Morning Herald: "Often when my ideas have been first proposed they were derided. Then, on the second time around, they are roundly applauded and embraced, but never connected with me." It has long been felt, even by his allies, that Jones was politically naive. In a highly factionalized party, he failed to develop a strong political base.

It was partially scientists' vocal dissatisfaction with funding cuts that raised the profile of Jones and his ministry. As late as last year, the Prime Minister acknowledged the vote-catching potential of science by providing increased funding. Jones's policy of "making science pay" is likely to be continued by the new minister.

Tania Ewing 